\title{
Respirable Crystalline Silica
}

National Cancer Institute

\section{Source}

National Cancer Institute. Respirable Crystalline Silica. NCI Thesaurus. Code C44441.

A widespread, naturally occurring, crystalline metal oxide that consists of different forms including quartz, cristobalite, tridymite, tripoli, ganister, chert and novaculite. Respirable crystalline silica is found in industry in metal and nonmetal mining and milling operations as well as in foundries, ceramic industries and at construction sites. Inhalation exposure to respirable crystalline silica causes chronic silicosis, emphysema, lymph node fibrosis and is associated with an increased risk of developing lung cancer. ( $\mathrm{NCl05)}$ 